\title{
Validitas dan Reliabilitas Metode Penilaian Student's Oral Case Analysis (SOCA) pada Mahasiswa Tahap Sarjana Kedokteran
}

\author{
Sylvia Mustika Sari
}

Fakultas Kedokteran Universitas Jenderal Achmad Yani, Cimahi

\begin{abstract}
Background: Oral case presentations will be a vital component in medical career. The Student Oral Case Analysis (SOCA) is the assessment method of students' ability in presenting their knowledge in case analysis, communication skills, and appropriate professional interactions. In fact, the studies in SOCA are still very limited. The aim of this study was to observe the validity and reliability of the oral assessment or SOCA in undergraduate medical education.

Method: The cross sectional study in the third year students in the Medical Faculty of University Jenderal Ahmad Yani. Content-related validity was achieved by a panel expert in developing case and guide for examiners in SOCA, while concurrent validity was achieved by the correlation between SOCA and MCQ results. Inter-rater reliability was estimated by kappa coefficient.

Result and Discussion: The panel expert has done to receive the content validity. As concurrent validity evidence, the correlation between SOCA and MCQ result was $0.441(\mathrm{p}<0.01)$. Inter-rater reliability with the result of Kappa coefficient was $0.893(\mathrm{p}<0.01)$.

Conclusion: The result shows that SOCA in undergraduate education was valid enough and reliable to assess the cognitive aspect.
\end{abstract}

Keywords: SOCA, assessment, validity, reliability, undergraduate.

\begin{abstract}
Abstrak
Latar Belakang: Presentasi kasus menjadi kegiatan yang penting dalam karir seorang dokter. Karenanya, sesuai strategi PBL, mahasiswa kedokteran memerlukan metode penilaian yang mengedepankan presentasi dalam menganalisis kasus sejak dini. Student Oral Case Analysis (SOCA) merupakan suatu metode penilaian yang dapat digunakan dalam menilai kemampuan analisis kasus pada mahasiswa dalam bentuk presentasi.

Tujuan: Untuk menilai aspek validitas metode SOCA dalam menguji ranah kognitif mahasiswa.

Penelitian dilakukan secara analitik cross-sectional pada mahasiswa tingkat tiga FK Unjani. Metode: Bukti content-validity dikumpulkan dengan pertemuan ahli (narasumber) dalam menyusun scenario dan petunjuk penilaian SOCA; concurrentvalidity dengan mengkorelasikan hasil ujian SOCA dan MCQ. Inter-rater reliability ditentukan dengan perhitungan koefisien kappa terhadap nilai dari dua penguji SOCA. Tinjauan ahli/narasumber terkait menyusun skenario SOCA berdasarkan pencapaian sasaran belajar dalam tutorial dan diskusi kelompok. Hasil dan Pembahasan: Korelasi nilai SOCA dengan MCQ sebagai bukti validitas lain adalah 0.441 ( $\mathrm{p}<0.01)$. Koefisien kappa (inter-rater reliability) adalah 0,893 ( $<<0.01)$.

Kesimpulan: Penilaian SOCA cukup valid dan reliabel dalam menguji kemampuan kognitif mahasiswa tahap sarjana kedokteran.
\end{abstract}

Kata Kunci: SOCA, validitas, reliabilitas, metode penilaian.

Korespondensi: Jl. Terusan Jenderal Sudirman - PO BOX 148 Cimahi \& Jl. Sarimanah no. 75 - Bandung 41051 No. Telp : (022) 6642782 / Hp. 0817-6262-84 Email: dr.vievoy@gmail.com 


\section{LATAR BELAKANG}

Presentasi kasus, merupakan salah satu aspek penting dalam karir seorang dokter. Secara profesional, seorang dokter dituntut untuk dapat melakukan analisis terhadap suatu kasus untuk membuat keputusan klinik yang tepat. ${ }^{1}$ Seiring dengan hal tersebut, telah dikembangkan suatu strategi pembelajaran berdasarkan kasus atau Problem Based Learning (PBL) melalui metode tutorial. Tutorial mahasiswa diharapkan dapat menganalisis secara kritis, mendebat atau mengemukakan pendapat secara ilmiah. Konsekuensinya, mahasiswa dituntut untuk dapat berkomunikasi secara aktif, mengembangkan diri, dan mampu mendengar serta menerima pendapat orang lain. $^{2}$

Perubahan strategi pembelajaran tersebut perlu disertai dengan perubahan dalam metode penilaian yang digunakan. Pada penilaian ranah kognitif, metode yang banyak dilakukan adalah dengan Multiple Choice Questions (MCQ). Banyak studi telah mengungkapkan bahwa metode ini memiliki validitas dan reliabilitas yang tinggi dalam menilai aspek kognitif. Namun, sesuai dengan strategi PBL, aspek kognitif mahasiwa ternyata perlu diintegrasikan dengan kemampuan komunikasi yang efektif serta profesionalismenya. Sehingga diperlukan suatu metode penilaian yang tidak hanya menilai aspek kognitif namun juga analisis, kemampuan komunikasi dan profesionalisme mereka dalam presentasi mengenai analisis suatu kasus.

Student Oral Case Analysis (SOCA) merupakan kesempatan mahasiswa untuk dapat mendemonstrasikan pengetahuan, keterampilan komunikasi dan interaksi ilmiah secara professional. Kesempatan tersebut dapat dimanfaatkan mahasiwa untuk meningkatkan kemampuan presentasi ilmiah. Hal yang juga penting dalam ujian lisan adalah kemampuan untuk mengukur kedalaman pengetahuan mahasiswa dan dapat mengendalikan plagiarism yang kemungkan terjadi pada ujian tulis. Ujian lisan juga terbukti mampu meningkatkan motivasi mahasiswa untuk belajar dan menganalisis suatu kasus. Di lain pihak, ujian lisan juga memiliki beberapa kekurangan diantaranya membutuhkan waktu yang cukup lama, dan memiliki kecenderungan bias oleh karena aspek subjektifitas dari penguji. Nilai mahasiswa dapat dipengaruhi oleh penampilan, gender bahkan unsur etnis. $^{3,4}$

FK Unjani yang telah melaksanakan KBK sejak tahun 2006 dan menggunakan tutorial serta diskusi kelompok sebagai bagian dari metode pembelajarannya, memutuskan untuk menggunakan ujian lisan. Namun, dalam menentukan metode penilaian yang digunakan, pelu dilakukan analisis berdasarkan beberapa kriteria yang dibuat berdasarkan bukti (evidence based) mengenai validitas, reliabilitas, dampak terhadap proses belajar, serta kepraktisan. ${ }^{5}$

Shumway dan Harden mendefinisikan validitas sebagai derajat kesesuaian pengukuran yang dapat dicapai oleh suatu instrumen penilaian terhadap hal yang harus diukur. Pencarian bukti validitas dapat dilakukan melalui content validity, criterion-related validity dan construct validity. Content validity banyak digunakan untuk menentukan validitas sistem penilaian dalam pendidikan. ${ }^{6}$ Linn dan Gronlund menyatakan content validity merupakan kesesuaian penilaian dengan kurikulum, hal ini dapat dicapai dengan membuat perencanaan penilaian yang dikenal dengan blue print. Penentuan content validity dapat ditempuh secara kualitatif maupun kuantitatif dengan Content Validity Ratio (CVR). Construct validity adalah menentukan apakah hasil penilaian dapat menginterpretasikan karakteristik individu yang berbeda. Validitas ini terutama digunakan dalam penilaian yang melibatkan tingkah laku yang mempengaruhi prestasi individu, seperti keterampilan, problem solving. Criterion-related validity adalah menentukan korelasi antara dua instrumen penilaian, terdiri dari predictive validity, yakni korelasi antar instrumen penilaian ditentukan dalam rentang waktu yang lama dan concurrent validity, bilamana korelasi antar instrumen ditentukan pada waktu yang hampir bersamaan dan menguji hal yang sama ${ }^{6,7}$ Berdasarkan hal tersebut, upaya pengumpulan validitas metode penilaian SOCA diawali dengan penyusunan blueprint penilaian untuk kemudian dilakukan tinjauan oleh ahli (narasumber) terkait 


\section{TUJUAN}

1. Mengetahui validitas metode penilaian SOCA dalam menguji aspek kognitif mahasiswa tingkat tiga tahap sarjana kedokteran di FK Unjani

2. Mengetahui reliabilitas metode penilaian SOCA dalam menguji aspek kognitif mahasiswa tingkat tiga tahap sarjana kedokteran di FK Unjani

\section{METODE}

Metode penelitian yang digunakan adalah analitik cross sectional, pada mahasiswa tingkat 3 Sarjana Kedokteran yang sedang menempuh Blok Sistem Hematologi dan Imunologi Klinik. Untuk menentukan concurrent-validity dilakukan analisis korelasi antara hasil ujian SOCA dangn MCQ, dan untuk menentukan reliabilitas digunakan perhitungan koefisien Kappa (inter-raterreliability) dengan mencari derajat kesamaan antara data nilai dari dua penguji SOCA.

\section{HASIL DAN PEMBAHASAN}

\section{Content Validity}

Dua minggu sebelum ujian berlangsung dilakukan pertemuan dengan narasumber terkait sesuai dengan skenario kasus. Penyusunan skenario didasarkan atas kasus yang digunakan dalam tutorial dan diskusi kelompok. Hasil peninjauan narasumber tersebut:

- Memilih kasus dengan level kompetensi tinggi (3 dan 4), dalam hal ini kasus yang dipilih untuk Blok Sistem Hematologi dan Imunologi Klinik adalah Anemia Defisiensi Fe, Steven Jhonson Syndrome, dan Reaksi Anafilaksis.

- Merumuskan hal yang perlu dijelaskan oleh mahasiswa pada saat presentasi kasus.

Analisis kasus dijabarkan sebagai berikut:

1. Merumuskan diagnosis berdasarkan case-overview

2. Merancang kerangka konsep analisis

3. Menjelaskan ilmu kedokteran dasar terkait kasus

4. Menjelaskan pathogenesis/ patofisiologi terkait tanda dan gejala pada kasus

5. Menjelaskan penatalaksanaan sesuai dengan konsep patofisiologi

6. Menjelaskan komplikasi dan prognosis pada kasus sesuai dengan konsep patofisiologi
7. Menjelaskan aspek bioetik, humaniora serta kesehatan masyarakat sesuai dengan kasus.

Hasil tinjauan ahli / narasumber terkait menunjukan bahwa metode penilaian SOCA cukup valid untuk menilai kemampuan kognitif mahasiswa, terutama dalam kemampuan analisis (C5-C6).

\section{Concurrent-Validity}

Sebagai bukti validitas lebih lanjut, dilakukan perhitungan koefisien korelasi antara hasil ujian tulis (MCQ) dan ujian SOCA dalam waktu yang hampir bersamaan dan menguji ranah kognitif mahasiswa yang termasuk dalam concurrent-validity. ${ }^{6}$ Untuk menentukan uji korelasi yang digunakan antara hasil ujian SOCA dan MCQ dilakukan uji normalitas dengan KolgomorovSmirnov (Z). Berdasarkan hasil pada Tabel 1, data nilai hasil MCQ dan SOCA dapat dinyatakan memiliki distribusi normal.

Tabel 1. Uji Normalitas ujian MCQ dan SOCA

\begin{tabular}{lcc} 
Data & $\begin{array}{c}\text { Absolut } \\
\text { (D) }\end{array}$ & $\begin{array}{c}\text { Deviasi distribusi } \\
\text { normal }(Z)\end{array}$ \\
MCQ & 0,700 & $0,710(p>0,05)$ \\
SOCA & 1,046 & $0,224(p>0,05)$ \\
\hline
\end{tabular}

Table 2. Uji Korelasi MCQ dan SOCA

\begin{tabular}{llll} 
& Statistik & SOCA & MCQ \\
\multirow{2}{*}{ SOCA } & Correlation Coef. & 1.00 & $0.441^{* *}$ \\
& Sig. (2-tailed) & & 0,000 \\
\hline \multirow{2}{*}{ MCQ } & Correlation Coef. & $0.441^{* *}$ & 1,00 \\
& Sig. (2-tailed) & 0,000 & \\
\hline
\end{tabular}

**) signifikan pada $(0,01)$

Sesuai dengan hasil pada Tabel 2, terdapat korelasi positif yang bermakna antara hasil metode penilaian SOCA dengan MCQ, dengan besar koefisien korelasi yang sedang. Adanya hubungan yang signifikan antara hasil kedua metode penilaian tersebut menunjukkan bahwa kemampuan mahasiswa dalam ujian SOCA dapat memprediksi kemampuan mahasiswa dalam ujian tulis (MCQ), begitu juga sebaliknya.

Dalam penelitian ini pencarian bukti validitas dilakukan dengan content validity yakni pembuatan blueprint dengan 
tinjauan ahli secara kualitatif. Hasil tinjauan ahli yang telah menunjukan bahwa scenario SOCA yang digunakan dalam cukup valid untuk menilai aspek kognitif mahasiswa. Untuk mengkonfirmasi bukti tersebut, dilakukan perhitungan koefisien korelasi antara hasil ujian SOCA dan MCQ dalam waktu yang hampir bersamaan, sehingga pengujian validitas tersebut termasuk dalam concurrent validity. Koefisien korelasi tersebut menunjukkan hubungan yang positif dan signifikan. Hal ini menunjukan kemampuan prediksi yang bermakna, sehingga ujian lisan (SOCA) yang berperan sebagai 'predictor' dapat memprediksi ujian tulis (MCQ) yang berperan sebagai 'criterion'. Dengan kata lain metode penilaian SOCA memiliki validitas yang cukup dalam menguji aspek kognitif mahasiwa.

\section{Reliabilitas Metode Penilaian SOCA}

Pengukuran reliabilitas pada penelitian ini dicapai dengan menentukan konsistensi penilaian dari dua atau lebih penguji (observer) yang disebut inter-rater consistency. Penentuan reliabilitas antar observer dilakukan untuk menghindari kesalahan yang diakibatkan oleh ketidaksesuaian standar nilai antar observer. Pengukuran reliabilitas antar penilai banyak dilakukan pada metode ujian esai dan observasi perilaku. ${ }^{7-8}$ Metode yang digunakan dalam menentukan reliabilitas antar penilai adalah dengan mengetahui persentase kesamaan nilai (percentage of agreement) dan melalui koefisien Kappa. Perhitungan koefisien Kappa pertama kali diperkenalkan oleh Cohen sebagai pengukuran kesesuaian antara dua penilai menggunakan skala nominal. Bila koefisien reliabilitas telah dihitung, maka untuk menentukan keeratan hubungan dapat digunakan kriteria Guilford, yaitu sebagai berikut: ${ }^{6-7}$

Kurang dari 0,20: Hubungan yang sangat kecil dan diabaikan, $0,20-<0,40$ : Hubungan yang kecil (tidak reliabel), 0,40 - < 0,70: Hubungan yang cukup reliable, $0,70-<0,90$ : Hubungan yang erat (reliabel).

Tabel 3. Koefisien Kappa (inter-rater reliability)

\begin{tabular}{lc}
\multicolumn{1}{c}{ Statistik } & Hasil \\
\hline $\begin{array}{l}\text { Kappa } \\
\text { (Measure of agreement })\end{array}$ & 0.893 \\
$\begin{array}{l}\text { Stdr Error } \\
\text { Signifikansi }\end{array}$ & 0.052 \\
\hline
\end{tabular}

Berdasarkan Tabel 3, maka dapat dikatakan bahwa metode penilaian SOCA tersebut reliable dalam menguji aspek kognitif mahasiswa. Penentuan reliabilitas tersebut tidak lepas dari unsur objektivitas yang telah diusahakan dalam bentuk daftar tilik serta tidak diperbolehkannya penguji untuk melakukan intervensi pada saat mahasiswa sedang melakukan presentasi.

\section{KESIMPULAN}

Metode penilaian SOCA dinilai cukup valid dan reliabel dalam menguji aspek kognitif mahasiswa. Namun masih diperlukan pengkajian lebih mendalam mengenai faktor yang dapat mempengaruhi validitas dan reliabilitas melalui penelitian psikometrik lainnya.

\section{DAFTAR PUSTAKA}

1. Jouhin G. A short guide to oral assessment. Available from:http://www.leedsmet.ac.uk/.../ 100317_3668_ShortGuideDrafAssess_WE. Leeds Metropolitan University and University of Wollongang.

2. Dolmans DH, Gijselaers WH, Moust JH, De Grave WS, Wolfhagen IH, Van de Vleuten CP. Trends in research on the tutor in problem-based learning: conclusions and implications for educational practice and research. Medical Teacher. 2002; 24(2):173-80.

3. SOCA Manual. Available from: http:// medapps.medicine.merger.edu//mu_medicine/ academics/.../bmpmanual.pdf. The New England Journal of Medicine. 12; 352(19):1945-6.

4. Sobel RK. Medicine as a second language. NEJM. 2005;352:1945-6.

5. Shumway JM, Harden RM. AMEE Guide No. 25: The assessment of learning outcomes for the competent and reflective physician. Medical Teacher. 2003; 25(6):56984.

6. Cohen RJ, Swerdlik ME. Psychological testing and assessment. An introduction to test and measurement. New York: Mc. Graw Hill; 2005.

7. Linn RL, Gronlund NE. Measurement and assessment in teaching. $8^{\text {th }}$ edition. Upper Saddle River. New Jersey: Merrill Prentice Hall; 2000.

8. Kaplan RM, Saccuzzo DP. Psychological testing. Principles, applications, and issues. California: Brooks Cole Publishing Company Pacific Grove; 1989. 